\title{
TEXTS ON VIOLENCE: OF THE IMPURE (CONTAMINATIONS, EQUIVOCATIONS, TREMBLING)
}

Textos sobre violencia: de lo impuro. (Contaminaciones, equívocos, temblores)

\section{Thomas Clément Mercier}

\author{
ANID/FONDECYT, Universidad Adolfo Ibáñez, Chile \\ thomas.clement.mercier@gmail.com
}

\begin{abstract}
:
This article interrogates a certain philosophical scene -one which constitutes itself through the position of what Jacques Derrida calls "the ethical instance of violence." In the course of the essay, I analyze this quasi-juridical scene through readings of Aristotle, Walter Benjamin, and Giorgio Agamben among others. The scene, built on texts on texts on violence, demands a logic of purity; it is wary of contaminations and equivocations. And yet it thrives on them. In analyzing the implications of text, writing, and trace for the philosophical discourse on violence, I follow Derrida "just to see" what could make the scene tremble.
\end{abstract}

\section{Keywords:}

Deconstruction, Law, Jacques Derrida, Giorgio Agamben, Walter Benjamin, Critique of violence, Justice.

\section{Resumen:}

Este artículo interroga cierta escena filosófica -una que se constituye a través de la posición de lo que Jacques Derrida Ilama "la instancia ética de la violencia". En el curso del ensayo, analizo esta escena cuasi-jurídica a través de las lecturas de Aristóteles, Walter Benjamin y Giorgio Agamben, entre otros. La escena, construida sobre textos sobre textos sobre violencia, exige una lógica de la pureza; es recelosa de contaminaciones y equívocos. Y sin embargo, se alimenta de ellos. Analizando las implicaciones del texto, la escritura y la huella para el discurso filosófico sobre la violencia, sigo a Derrida "solo para ver" qué puede hacer temblar esta escena.

\section{Palabras clave:}

Deconstrucción, ley, Jacques Derrida, Giorgio Agamben, Walter Benjamin, crítica de la violencia, justicia. 
A text is a text only if it hides from the first glance, from the first comer, the law of its composition and the rule of its game $[j e u]$. A text always remains, for that matter [d'ailleurs], imperceptible. The law and the rule are not sheltered in the inaccessibility of a secret; it is simply that they never give themselves, in the present, to an$y$ thing that could rigorously be called a perception.

Derrida, 1981: 63, translation modified.

What happens is always some contamination. The uniqueness of the event is this coming about of a singular relation between the unique and its repetition, its iterability. The event comes about, or promises itself initially, only by thus compromising itself by the singular contamination of the singular and what shares it. It comes about as impurity -and impurity here is chance.

Derrida, 1992a: 68-69.

\section{CONTAMINATIONS: OF A PHILOSOPHICAL SCENE ("THE ETHICAL INSTANCE OF VIO- LENCE")}

It might seem counterintuitive to start an essay on violence with two epigraphs that deal with text and literature. The first epigraph is the famous incipit of Derrida's "Plato's Pharmacy," while the second one is extracted from a 1989 interview on the "institution" of literature. Of course, my choice of epigraphs is not entirely innocent. I will give two justifications for it. First, my intention was to draw attention to the textual character of what I will call a philosophical scene. This scene supposes a certain "style" of writing or doing philosophy, and perhaps even a certain philosophical "genre" or "subgenre": the philosophical discourse on violence. The scene involves a mise en scène, always more or less fabricated, in which the philosophical discourse gives itself the power or the authority to deliberate about violence, to make "violence" its object, to delineate violence, to delimit between violence and its other (nonviolence), or to discriminate between just or unjust, legitimate or illegitimate categories of violence. This gesture supposes the expulsion or obfuscation of the violence of its own doing, of its own fabrication; it suggests that what we call violence can be made available to a relatively neutral theoretical discourse, so that predicative judgements can be made on violence, on the distinctions between violence, force, or power, on the possibility and sometimes the necessity of violence, and so on. The philosophical discourse posits itself as a theory of violence and grants itself the power to draw ethical-political implications in the form of a critical instance. In doing so, the philosophical discourse delimits a regional field over which it gives itself the authority to legislate. In this scene, the philosopher already resembles a legislator or a legal constituent; the philosophical text already starts to resemble a legal constitution. One can find many illustrations of this theoretical-practical "scene" in the history of Western 
philosophy, from Plato and Aristotle to Hobbes and Rousseau, Hegel, Marx, Benjamin, Weber, Sartre, Fanon, Arendt, Agamben, Butler, and so on and so forth. But here, already, the scene I describe -the philosophical discourse on violence- becomes enmeshed with problems of language: how will we recognize the unity of that thing called "violence" through all its translations, anamorphoses, and definitions? Is there a continuous line from the Greek ís and ßí $\alpha$ (force, violence) to the Latin vis and violentia -to say nothing of the vastly different German Gewalt and of its cognates? Etymology can only take us so far. But since we must start somewhere, let me quote Aristotle's Nicomachean Ethics. Book III starts with a reflection on $\beta$ í $\alpha$ (violence) and includes a definition of the Bíaıs (violent) act (1110b):

That which is violent [ßíaıv] is something whose origin [à $\rho x \grave{\eta}]$ is external $[\tilde{\varepsilon} \xi \omega \theta \varepsilon v]$, since it is the sort of thing to which the person who is acting or undergoing something contributes nothing -for example, if a wind, or people who have control over someone, should carry him off somewhere. [...]

What sort of actions, then, are to be called violent [ $\beta i^{\prime} \alpha\llcorner\alpha]$ ? [...] That which

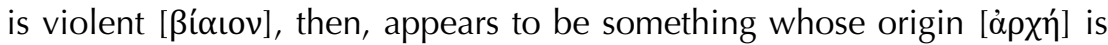

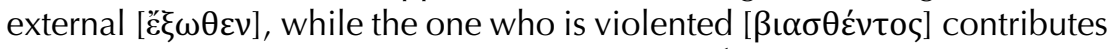
nothing to it. (2011, 42-44; translation modified ${ }^{1}$ )

Does this amount to a definition of violence? At the very least, the scene here described by Aristotle is a scene of appellation, of classification. An action is said to be violent, then, if it has its origin -its arkhe- entirely outside of whom or what is being "forced" or "violented". Violence comes purely from the outside, as exo-archy. Violence, in this perspective, presupposes the existence of an inside/outside structure, of a certain limit between the two, and must be understood as generated from the outside, as exogeneous or exonomic, heterogeneous or heteronomic. Itself inscribed in a text that is a pedagogical treaty of ethics, this scene would constitute an example of what Derrida calls "the ethical instance of violence" (I will return to this "instance" in a moment).

This leads me to my second justification for choosing epigraphs that deal with text. It brings us closer to Derrida. In his reading of Rousseau and Lévi-Strauss in Of Grammatology, Derrida approached violence -and, in fact, "originary violence" -through a certain scene of writing:

For writing, obliteration of the proper classed in the play of difference, is the originary violence itself: pure impossibility of the "vocative mark," impossible purity of the mark of vocation. This "equivocation," which Rousseau hoped would be "eliminated" by a "vocative mark," cannot be effaced. For the existence of such a mark in any code of punctuation would not change the problem. The death of absolutely proper naming, recognizing in a language the other as pure other, invoking it as what it is, is the

\footnotetext{
${ }^{1}$ What does justify, here, that ßíaıs be translated as "violent" rather than "forced," or "constrained," or "compulsory," or even "exogeneous"? What does remain of $\beta$ í $\alpha$ when it has been reduced to the supposed kernel of this definition, that is: to the purely exogeneous or the heterogeneous (supposing that this gesture of definitional reduction is indeed possible)? And what does lie in this definition -if not, already, the whole text-machinery of the Nicomachean Ethics and the powerful system of traces it carries with itself?
} 
death of the pure idiom reserved for the unique. Anterior to the possibility of violence in the current and derivative sense, the sense used in "A Writing Lesson," there is, as the space of its possibility, the violence of the arche-writing, the violence of difference, of classification, and of the system of appellations. (1997: 110)

What Derrida calls "originary violence" -"the violence of difference, of classification, and of the system of appellations"- is thus inseparable from a thinking of writing. It supposes the impossibility of "purity" -that of the proper and of the unique, which can be seized as such only through the differantial effects of iterable marks, traces, and references. Akin to the law of iterability described in our second epigraph, archewriting involves impurity, equivocation, and contamination:

To think the unique within the system, to inscribe it there, such is the gesture of the arche-writing: arche-violence, loss of the proper, of absolute proximity, of self-presence, in truth the loss of what has never taken place, of a self-presence which has never been given but only dreamed of and always already split [dédoublée], repeated, incapable of appearing to itself except in its own disappearance. (1997: 112)

"Arche-violence" or "originary violence" would thus refer to the "violence" of referentiality "itself" -in other words, to the heterogeneity of self-difference (self-interruption or différance) which pre-conditions the position of the discourse on presence. In this sense, arche-violence is nothing present. It cannot present itself. It cannot be conceived or experienced in the form of presence. It "is" not. It is not "of" being. It is certainly not an ontological violence and cannot be reduced to ontological concepts of violence (be they theoretical or empirical) ${ }^{2}$. No concept for it. It precedes and

\footnotetext{
${ }^{2}$ In a recent essay, Bruno Bosteels (2017) claims that Derrida produces an "ontologization" of "originary violence" which prevents him from appreciating the historical-dialectical dimension of violence and counter-violence (such as revealed to us by Hegel and Marx), and forbids any meaningful or effective critique of power and violence. Let's note that Bosteels makes these claims without ever offering any reading of Derrida's texts on violence. He merely quotes from his 1964-1965 seminar on Heidegger, and interprets Derrida's readings of Heidegger as exemplifying Derrida's position on the "ontological" dimension of polemos. In the pure style of the traditional metaphysician, Bosteels goes to the text as if it were merely a reservoir for truth content, for algebraic concepts, and completely ignores what makes a text a text: here, a seminar in which Derrida teaches Heidegger. Bosteels claims to speak about "the early Derrida," but it would have been enough for him to go to "Violence and Metaphysics" or Of Grammatology (both elaborated in the same years) to realize the problems with his argument. The violence of Bosteels's interpretation is evident; and it can be critiqued. Indeed, contrary to what Bosteels claims, Derrida's deconstruction of violence does not "ontologize" violence. It supposes an increased attention to contexts, "historical" or else. By showing that there is no acontextual violence, it raises the stakes for historicity by challenging traditional (for example Hegelian-dialectical) conceptions of history. Therefore, Derrida's economy of violence does not eliminate the reference to historicity or criticality; however, through the postulation of what he names an "unrecognizable history" (2002: 257), Derrida reinscribes historicity and criticality within a more general historicity (a sort of hyper-historicity) emphasizing the silencing violence and originary performativity of the critical and historical gestures inasmuch as they contribute to violently stabilize the reference to violence in a given context. I addressed at length the question of the articulation between violence and historicity in my $\mathrm{PhD}$ dissertation The
} 
exceeds any conceptuality and any ontology, as well as any ontological discourse that could be made on the subject of violence (in the derived sense of the term). The ontological gesture works in obfuscating the originary "violence" of heteronomic referentiality, although it proceeds from it. The sovereign gesture of ontology must protect its "own" autotelic, self-referential structure against the "violence" of heteronomy and ex-appropriation, while it relies on it for its "own" position: the logic of the proper and the thought of presence are but effects of heteronomic referentiality and its supposed "violence." I use scare quotes, here, because the "violence" at stake can be conceived as violence (in a derived sense, then: as heteronomic violation of the self, of full presence) only from the standpoint of the ipseity of a proper which sees itself as threatened by heteronomy in its "origin," before its "origin." For a similar reason, "originary violence" is "originary" only from the standpoint of a thought of origin: in a perhaps more rigorous sense, "originary violence" is what deprives the autonomic structure of ipseity from "origin." 3 Because it refers to the irreducible referentiality of text, to the alwayspossible substitutability of traces, to self-difference and heteronomy as pre-conditions for thought, discourse, and experience, arche-writing can only be conceived as violent (in the derived sense) from the perspective a philosophical "scene" which privileges self-presence and the logic of the proper in its representation of thought, discourse, and experience. It is on the basis of this important distinction that arche-writing can be understood as "violent opening":

To recognize writing in speech, that is to say differance and the absence of speech, is to begin to think the lure. There is no ethics without the presence of the other but also, and consequently, without absence, dissimulation, detour, differance, writing. The arche-writing is the origin of morality as of immorality. The nonethical opening of ethics. A violent opening. As in the case of the vulgar concept of writing, the ethical instance of violence must be rigorously suspended in order to repeat the genealogy of morals. (1997: 140)

As radical opening, différance cannot be said to be violent or nonviolent in the derived sense of violence -that is, according to more or less stabilized critical discriminations resulting from the (more or less fabricated) scene which posits "the ethical instance of violence." However, it opens "the space of its possibility." As Derrida explains, this does not mean that writing should be understood as purely and simply "innocent"; he agrees with Rousseau and Lévi-Strauss that there might be something intrinsically "violent" about writing from the perspective of speech and full presence. However, what we call here "violence" must be rethought entirely, and disjointed from strictly ethical and empirical readings of violence: "radicalizing this theme, no longer considering this violence as derivative with respect to a naturally innocent speech, one reverses the entire sense of a proposition -the unity of violence and writing- which one must therefore be careful not to abstract and isolate" (1997: 106, my

Violence of Legitimacy: Democracy, Power, Antagonism (King's College London, 2017), which I am currently turning into a book.

${ }^{3}$ For both these reasons -and although I agree at large with Valeria Campos-Salvaterra's analyses of violence in relation to deconstruction and phenomenology (2019)- I would not call this originary violence an "original polemos." 
emphasis). Let's be careful, then. Especially because, as we will see, this non-derivative sense of "violence" ("originary violence"), as heteronomic curve or hetero-referentiality, is also described by Derrida as the condition for the relation to the other. As Derrida explains in "Violence and Metaphysics," the same necessities are conditions for both "violence" and "nonviolence":

these necessities are violence itself, or rather the transcendental origin of an irreducible violence, supposing, as we said above, that it is somehow meaningful to speak of preethical violence. For this transcendental origin, as the irreducible violence of the relation to the other, is at the same time nonviolence, since it opens the relation to the other. It is an economy. And it is this economy which, by this opening, will permit access to the other to be determined, in ethical freedom, as moral violence or nonviolence.

(1978: 160) $)^{4}$

${ }^{4}$ If I quote this passage and stress the notion of "nonviolence" in this introduction, it is certainly not to claim to retrieve a beatific relation to the other oriented towards perpetual peace and whatnot. It is, rather, to express a certain perplexity with regard to several readings which reduce Derrida's deconstruction of violence to the recognition of the ineradicability of what they call "constitutive violence." Certainly, Derrida gives many indications that there is a certain empirical ineradicability of violence. But the risk is to conflate the "arche-violence" of arche-writing with ontological or empirical concepts of violence, and thus to reinstitute, by the same token, "the ethical instance of violence," though negatively, now understood as constitutive violence and as impossibility of the ethical relation. For example, Martin Hägglund (2008) cites as epigraph to his chapter on "Arche-Violence" (76) the passage that just precedes the above quotation from "Violence and Metaphysics"; but he never mentions Derrida's important caveat ("supposing [...] that it is somehow meaningful to speak of preethical violence") and erases all references to "nonviolence." Why oversimplify Derrida's argument on preethical violence and/or nonviolence? This, I believe, is related to Hägglund's overall intent, which is to offer an account of deconstruction as purely descriptive, and to debunk prescriptive or ethical "misreadings" of Derrida (31). Hägglund is right to say that the "opening" we are talking about here is not strictly "ethical"; it is preethical. But this is precisely the reason why it is neither violent nor nonviolent in the ethical (derived) sense of term. Nonetheless, Hägglund insists that Derrida's critique of Levinas signifies the ineradicability of what he calls "constitutive violence," which implies that the nonviolent relation to the other cannot exist (or even be desired) as such. In this way, Hägglund posits the irreducibility of violence, the necessity of discrimination and struggling, and the need to interminably calculate between violences within an economy of violence. This is perhaps true from an empirical or descriptive perspective: no determinate relation to the other can ever be said to be purely nonviolent -or purely violent, for that matter, which is enough to (at least) problematize the notion of "constitutive violence." But the issue is that Hägglund's purely "descriptive" account is reductive and one-sided: Michael Naas (2009) persuasively showed that Hägglund's insistence on descriptivity cannot not fall back into an ontological description of différance, trace, and spacing as what arrives in/to a presence. Similarly, Hägglund reduces arche-violence to a negative impossibility (empirical violence) precluding the ethical relation to the other; he fails to account for the fact that it is a structural condition of possibility and impossibility for thinking the relation (see also Vitale [2018: 228-9] for a similar critique of Hägglund with respect to autoimmunity). Derrida, in his writings on violence, strives to think this pre-ontological opening, which he also calls an irreducible promise (1996: 85). The opening of the promise suspends the ethical instance of violence. It is neither violent nor nonviolent in the derived sense of the term -or it is perhaps both, or perhaps something else entirely, because in fact it "is" nothing in itself, nothing present. It 
This transcendental violence/nonviolence -which is, from the outset, described as condition of possibility and impossibility- is certainly what Derrida will refer to in later texts as a quasi-transcendental. It refers to the contaminating effects of différance and text as auto-hetero-referentiality.

Of course, Derrida's insistence on text does not mean that violence should be understood as purely "textual" -or, even less, as a purely "linguistic violence," as claimed by Beatrice Hanssen (2000: 165-78). It signifies that what we call violence, or ßí $\alpha$, Gewalt, or violencia, or what we refer to through the whole lexicon of force, power, potestas, potentia, potenza, puissance, and so on, is always differantial and referential. It is taken within the trace-structure. This implies that the (philosophical) thinking and meaning of violence always departs from traces -which can always be interpreted as "traumas" (either positive or negative)- and that what we place under the name violence cannot be conceptualized as such, that is, seized within a concept that would be univocal, fully unified and self-identical. The "concept" of violence (supposing there is one) is always inscribed within more or less stabilized, contextual networks of referential traces which remain to be interpreted, and perhaps deconstructed. ${ }^{5}$ The risk, of course, is that interpretive readings of violence are always contextual -and this is one of the first violences of violence: I am always potentially robbed of my conscious or unconscious experience of violence. The economy of violence is quite as much an economy of justifications. This also means that violence remains to be interpreted, translated, and, perhaps, repaired, on the backdrop of a singular experience which, in itself, remains inaccessible to any conceptuality and philosophical

must be interpreted through traces. It remains to be read. In The Politics of Friendship, Derrida calls it "a strange violence" (2005: 231). It points to a radical heteronomy before autonomy, to "the pre-originary intervention of the other in me" (2001: 89) -an "intervention" which, if we take it seriously, goes to deconstruct Hägglund's opposition between "prescription" and "description." In beckoning to this pre-originary and preethical indebtedness to the other, deconstruction does something and enjoins something; it suggests, at the very least, the force of an injunction, the "strange violence" of this pre-originary opening and contamination, "the heteronomic and dissymmetrical curve of a law of originary sociality" (2005: 231, translation modified). If, in this essay, I chose -unlike Hägglund- to put much emphasis on the question of text, it is notably to try and avoid the problematic opposition between (ontological) description and (ethical) prescription when it comes to "violence." A text is never purely "descriptive," nor simply "prescriptive." I'll draw several implications of this in conclusion.

${ }^{5}$ See Derrida (1988): "The phrase which for some has become a sort of slogan, in general so badly understood, of deconstruction ('there is nothing outside the text' [il n'y a pas de horstexte]), means nothing else: there is nothing outside context" (136). "The structure thus described supposes both that there are only contexts, that nothing exists outside context, as I have often said, but also that the limit of the frame or the border of the context always entails a clause of nonclosure" (152). "This is why (a) the finiteness of a context is never secured or simple, there is an indefinite opening of every context, an essential nontotalization; (b) whatever there can be of force or of irreducible violence in the attempt 'to fix the contexts of utterances,' or of anything else, can always communicate, by virtue of the erasure just mentioned, with a certain 'weakness,' even with an essential nonviolence. It is in this relationship, which is difficult to think through, highly unstable and dangerous, that responsibilities jell, political responsibilities in particular" (137). 
discourse, any ontology. Violence is a heritage -and, in large part, a philosophical heritage- itself inscribed through texts, contexts, notions, representations. The question remains to know how we use (or abuse) this heritage, what we can or should do with this heritage -although the problem might not be "simply" that of using or doing something, but of reading, writing, and deconstructing, which is perhaps something else.

If, as we saw above, violence and writing share an intimate relationship of coimplication (as heterogenous or differential this relationship might be), we can assume two things: 1 ) that every text-starting with Derrida's- has to do with violence, is a text on violence; and 2) that the motif of violence cannot be reduced to a "question" or a "theme" among others in Derrida's corpus -and that this motif is virtually unlimited, although, due to the law of quasi-transcendental contamination exposed above, it is never quite identical with itself. The law of text "suspends" the ethical instance of violence and the philosophical scene that is attached to it. Let's recall what Derrida says about the violence of academic discussion (and beyond) in Limited Inc:

\begin{abstract}
The violence, political or otherwise, at work in academic discussions or in intellectual discussions generally, must be acknowledged. In saying this I am not advocating that such violence be unleashed or simply accepted. I am above all asking that we try to recognize and analyze it as best we can in its various forms: obvious or disguised, institutional or individual, literal or metaphoric, candid or hypocritical, in good or guilty conscience. And if, as I believe, violence remains in fact (almost) ineradicable, its analysis and the most refined, ingenious account of its conditions will be the least violent gestures, perhaps even nonviolent, and in any case those which contribute most to transforming the legal-ethical-political rules: in the university and outside the university. (1988: 112)
\end{abstract}

For all these reasons, no text is ever entirely innocent -which also means that, for the same reasons, no text is ever entirely guilty as text... With all these precautions in mind, let me add a last one to conclude this introduction. This text is not a text on violence. This text is a text on texts on violence. I cannot tell if that makes me more or less innocent.

\title{
2. EquiVOCATIONS: Of A teXt (Yet ANOTHER TEXT ON “DIVINE VIOLENCE”...)
}

Let's start with a text: Walter Benjamin's Zur Kritik der Gewalt, first published in 1921. It is a short text, but one which generated an enormous amount of literature: texts on texts on a text. It would be impossible to list here all the commentaries that were written on Walter Benjamin's essay. The list becomes gigantic if one adds the texts written on Derrida's text ${ }^{6}$ on Benjamin's text, to which one should also add the texts written on Agamben's texts on Derrida's text on Benjamin's text: "Since the appearance of Derrida's discussion, Benjamin's essay has been more and more minutely scrutinized, analysed, dissected, and has provoked a wide range of different and

\footnotetext{
6 "Force of Law: The 'Mystical Foundation of Authority" (in Derrida, 2002: 230-298). Derrida's essay was first given as lectures in 1989-90. The bulk of the section on Benjamin was initially part of Derrida's seminar Politiques de l'amitié (EHESS, 1988-89).
} 
diverse, and often conflicting, interpretations by thinkers as distinct as the aforementioned Axel Honneth, Judith Butler, Simon Critchley and Slavoj Žižek (to name just a few)" (Moran and Salzani, 2015: 4-5). This intricate network of texts on texts on violence seems to function as a gargantuan interpretive machine, a phantasm factory put to work by a multitude of psychic and theoretical investments. In several places of his book Violence: Thinking without Bannisters, Richard Bernstein seems to recognize the quasi-sexual appeal of the text -one that is "irresistible": "In seeking to make sense of violence and to distinguish types of violence (and nonviolence) there is an almost irresistible obsession to return to Benjamin's essay and to take one's stand in regard to it" $(2013$, 48). Bernstein speaks about the text's "seductive allure" -which doesn't preclude a certain "nervousness," especially regarding the concept of "divine violence." The fantastical interpretive scene we are approaching here (Giorgio Agamben uses the term "gigantomachy") is not without desire, sex, and violence. It bridges the theoretical and the practical, the spiritual and the concrete in interpretations at war: "More generally, these several interpreters are fighting for the soul of Benjamin. The issue is not exclusively whether one is to read Benjamin as a philosophical, political, theological, or political-theological thinker. Rather, what underlie the conflict of interpretations are the concrete consequences of Benjamin's thinking." But, I might add: what if this text were -dare I say- a text? If Benjamin's text-machine works, and works apparently so well, in so many different contexts, it is perhaps because it is also a text, and as such is open to interpretations and equivocations: in fact, the text-machine exhibits this openness -an intrinsic fallibility which leaves the reader affected in a way that is immediately generative.

Many of these theoretical-psychosexual-textual investments have fixated on the concept of "divine violence" -despite, or perhaps because of, the fact that divine violence is defined by Benjamin as both pure and impure ("bastardized"), and remains inaccessible to human interpretation:
But if the existence of violence beyond the law, as pure immediate vio- lence, is assured, this is proof that revolutionary violence -the name which must be assigned to the highest manifestation of pure violence among men- is possible, and how. However, it is neither possible nor urgent for humankind to decide when pure violence was actual [wirklich] in a given case. For only mythic violence, not divine violence, will be recognizable as such with certainty, unless it be in incomparable effects, because the expiatory force of violence [die entsühnende Kraft der Gewalt] does not manifest itself to men. Once again all the eternal forms are open to pure divine violence, which myth bastardized with law. (Benjamin, 1996: 252, translation modified)

For these reasons, pure divine violence fosters equivocations and misunderstandings. Not only because "divine violence" is itself a textual piece, inscribed within a text which is itself admittedly difficult, but also because equivocation and misunderstanding are inscribed by Benjamin in its very concept. ${ }^{7}$ Agamben, for example, underlines its dangerous power of equivocation:

${ }^{7}$ Given Benjamin's important caveat, there is something quasi-tragicomical in the way readers keep denouncing previous "misreadings" of divine violence -just before putting forward their 
The definition of this third figure, which Benjamin calls "divine violence," constitutes the central problem of every interpretation of the essay. Benjamin in fact offers no positive criterion for its identification and even denies the possibility of recognizing it in the concrete case. What is certain is only that it neither posits nor preserves law, but rather "de-poses" (entsetzt) it. Hence its capacity to lend itself to the most dangerous equivocations [equivoci] (which is proven by the scrutiny with which Derrida, in his interpretation of the essay, guards against it, approximating it -with a peculiar misunderstanding [singolare fraintendimento]- to the Nazi "Final Solution." (1998: 63-64)

If I had to schematize the question that awaits us, I would put it this way: Agamben's reading of divine violence is an attempt to stabilize the equivocation and to protect divine violence at all costs against potential "misunderstandings." (One could argue that Agamben's whole argument in State of Exception is oriented towards this goal, notably by disjoining Benjamin from Carl Schmitt as carefully as possible.) On the contrary, Derrida's interpretation consists in emphasizing interpretability and the risk of equivocation at every turn, making it the starting point of his reading, and stressing the irreducible possibility of misreading, complicities, and contaminations.

own (supposedly) "correct" reading of it. For a recent example, see Judith Butler (2020). Since we're on the topic of "recognizing" divine violence, let's bring up an interesting document that was recently brought to Benjamin scholars' attention (notably by Sami Khatib). It is an entry in Werner Kraft's diary dated from May 1934, in which Kraft describes a private conversation with Benjamin (in Scheurmann, 1992: 47). Kraft reports that Benjamin told him in 1934, about 13 years after the publication of Zur Kritik der Gewalt, that he now considers "divine violence" as "an empty spot, a limit-concept, a regulative idea" (my translation). Kraft explains that Benjamin now believes that the "just war" of "divine violence" is the class struggle. This is great news for Slavoj Žižek (2016: 39-42), who sees there a confirmation that divine violence designates "brutally unjust," radically meaningless, strictly destructive manifestations of the class struggle: pure means without end. This is perhaps the case, but: 1) in the same diary entry, Kraft also explains that Benjamin still considers (just) divine violence (in the form of the "class struggle," then) as radically nonteleological, as pure violence disconnected from any mythical belief, end-oriented rationalization or justificatory narrative. Violence becomes unjust (for example, in the case of fascist violence) as soon as it is inscribed in justificatory discourse. So that all problems of interpretation, justification, representation, identification and recognition related to "divine violence" (on which I have more to say below) should now also affect or contaminate whatever bears the name "class struggle." It is unclear whether this problematization of the class struggle can be made fully compatible with Žižek's own conception of the class struggle, and with the examples he takes to illustrate such conception in relation to "divine violence"; 2) but let's not forget that the document we are talking about here is a very singular text: it is a personal account of a private conversation, written privately by Kraft (what a name!) in 1934 (what a date!). Let's also note that Kraft is often critical of Benjamin (and of his proto-Marxism) in his diary -which also contains violent accusations of lying and injustice, conflicts in paternity claims (around the work of Jochmann), but also declarations of love and veneration, as well as expressions of painful disappointment followed by outbursts of forgiveness... How does one read such a text? 
Benjamin's explicit intent in "Zur Kritik der Gewalt" is, well, to produce a critique of violence. ${ }^{8}$ From the outset, Benjamin exposes the main difficulty of this project: it is made difficult by the very nature of law, of any legal system, which has always determined violence as a means to an end. The result is that violence, as means, can always be justified in relation to its end. The essence of law, of any legislation (natural or positive) is to distribute between violence and nonviolence, between justified and unjustified violence. In the sphere of law, nothing definitive can be said about the legitimacy or illegitimacy, justness or injustice of violence, because this judgement will be indexed on the state of law, on the law of the state and the legitimacy of its ends, themselves instituted and protected through violence. One cannot escape a certain dogma: "just ends can be attained by justified means, justified means used for just ends" (1996: 237). In order to escape this circle of violence and law -the apparently interminable cycle of justified violence and violent justifications, of law-positing and law-preserving violences, the dialectics of revolutions and counterrevolutions- Benjamin reaches for two motifs that seem to exceed the sphere of law and its means-ends structure: "nonviolent pure means" and "pure divine violence." Benjamin gives several examples of nonviolent pure means (for example, a certain conception of noninstrumental language); but he also suggests that the politics of pure means can always be colonized by law and become impure, and therefore violent. The state's law can always interpret those pure means as violent, not because of their nature as such (Benjamin seems to hold onto the idea that pure means are intrinsically nonviolent), but because they can be judged to be violent due to their effects. A case in point is the revolutionary proletarian strike, which Benjamin describes as a nonviolent pure means, but which is perceived as violent and threatening by the state (246). Resistance and repression ensue. The nonviolence of "pure means," then, can always be considered as violent, not because of what it is, but because of what it does. And Benjamin, who is clearly sympathetic towards a purely nonviolent anarchistic revolutionary strike, also seems to suggest that its chance of deposing the law once and for all are very limited "if violence is totally excluded in principle" (247). ${ }^{9}$ This is when "divine violence" enters the stage.

I would be careful not to fully conflate what Benjamin calls "pure means" with what he calls "divine violence." While pure means are understood as essentially

\footnotetext{
${ }^{8}$ I analyze Benjamin's essay in more detail -especially in relation to a certain "performative violence" - in my PhD dissertation, The Violence of Legitimacy: Democracy, Power, Antagonism. In "Force of Law," Derrida recalls that "violence" is not a perfect equivalent for Gewalt: "The text by Walter Benjamin that I will be speaking about soon is entitled 'Zur Kritik der Gewalt'; translated in French as 'Pour une critique de la violence' and in English as 'Critique of Violence.' But these two translations, while not altogether unjust, and so not entirely violent, are very active interpretations that do not do justice to the fact that Gewalt also signifies, for Germans, legitimate power, authority, public force. Gesetzgebende Gewalt is legislative power, geistliche Gewalt the spiritual power of the church, Staatsgewalt the authority or power of the state. Gewalt, then, is both violence and legitimate power, justified authority" (2002: 234).

${ }^{9}$ In the 1920 fragment "The Right to Use Force," Benjamin expresses similar doubts about the strategy of nonviolence, and about "ethical anarchism" as viable political program (1996: 233).
} 
nonviolent, divine violence is never explicitly described as nonviolent: it is pure violence. Certainly, there might be points of passage between the two (for example, pure, divine violence, which is entirely outside of law, is certainly not a means to an end, even less a human end); but it is worth noting that Benjamin, in that text, never literally describes divine violence as "pure means," or as nonviolent. I say this because many commentators have jumped to the conclusion that divine violence, as pure violence, can be interpreted as an instance of nonviolence and as a pure means. Perhaps, but I am not sure that this is quite the case -maybe divine violence is something else entirely. It is absolutely decisive beyond the law. Its principle is justice without justifications. It is pure violence (Gewalt) without power (Macht). It is a pure manifestation of Gewalt which exceeds the legal circle of justifications and condemnations. As such, it exceeds human interpretation and decision.

Why is it so important that divine violence -the expiatory force ( $\mathrm{raft}$ ) of justice, as pure, immediate self-manifestation of violence beyond the law- remains uninterpretable according to Benjamin? This is because, as soon as justice and its violence are interpreted, they can always be justified and/or condemned, and thus reinscribed within the logic of justifications, that is, within the teleo-logic of the means-ends structure which is the essence of the legal system -and more generally, of the philosophical "scene" of violence understood as ethical-juridical machine. In other words, as soon as violence can be interpreted and represented, it can enter the economy of violence and justification, and it is always possible that justice becomes contaminated, bastardized by law. Interpretation is always, at least virtually, a scene of judgement, of impure violence and justification. Such possibility can never be excluded as soon as pure violence is deemed interpretable and representable: it can always be reincorporated within the ethical economy of morality and immorality, violence and nonviolence, guilt and innocence. Violence can be justified or legitimized, excused or mitigated, disculpated, maybe forgiven, found innocent and perhaps even nonviolent -which also means, by the same token, that it can always be incriminated, inculpated, condemned, or denounced, sometimes within the same "scene" of judgement. Interpretability makes pure violence potentially impure by making it possible to judge it and give reasons for it, to inscribe it within a chain of causality, to make it a means to an end. It makes testimony possible, be it for the defense or the prosecution -à charge ou à décharge. But, in principle, divine violence should not need to justify "itself," because if it did, it would mean that God "himself" would be a subject of law -and no absolute criteria for justice and/or violence would be given any longer. Purity -that of violence, just violence, pure divine violence- cannot survive interpretation; it is always threatened by interpretability.

Benjamin's gesture is thus explicitly ambivalent: while he makes it clear that pure divine violence remains radically uninterpretable in itself and in its effects, he does preserve, in the figure of divine violence, the possibility of a pure Gewalt in which violence and justice are conflated. ${ }^{10}$ Divine violence is uninterpretable, but it is just:

\footnotetext{
${ }^{10}$ It is perhaps this dangerous ambivalence of divine violence -uninterpretable though effective; pure though bastardized- which interested, excited, and troubled Derrida so much enough to justify (without it being entirely justifiable, and explicitly so) his provocative interpretation in the "Post-Scriptum" of "Force of Law." In turn, Derrida's forceful, perhaps violent
} 
it is an effective manifestation of violence as justice -although its scope and even its effects escape the power of decision and interpretation of humankind. In Zur Kritik der Gewalt, Benjamin does not explicitly describe divine violence in the language of ontology, but it is undeniably an instance of pure violence as justice, of violence and justice as such, conceived in the purity and immediacy of a pure self-manifestation of violence as such. Question: can a discourse on purity ever fully escape the language of ontology? In any case, it is necessary that pure divine violence remains both effective (wirklich) and uninterpretable as such, because any interpretation of divine violence would make it impure by reincorporating it into the economy of justification predicated on the means-ends logic. Pure divine violence would thus become contaminated by law -which, according to Benjamin, may always happen. ${ }^{11}$

interpretation provoked, troubled, and excited -generating interpretations over interpretations: texts on texts on violence.

${ }^{11}$ Everything, therefore, hinges on the way one chooses to read or interpret this always-possible contamination of justice by law -a very difficult problem, made all the more difficult because interpretative reading itself can always be interpreted as effecting contamination. I believe there are at least three ways of interpreting the problem of the contamination between justice and law in relation to divine violence: (1) The first one is to localize, identify, and protect, against contamination, certain instances or examples -ontological categories of human practices strictly uncontaminated by law. This is, for example, James Martel's reading of divine violence as a political ontology of nonlegal anarchistic practices (2015), or Žižek's conception of divine violence as purely destructive outbursts of lawless violence (2016), or Judith Butler's interpretation of it as nonviolent civil resistance against the violence of law (2020). This is also Agamben's interpretation, as will be described in this section: a modal ontology of human life as pure potential, whose purity remains uncontaminated by the teleo-logic of law. (2) The second type of interpretation, perhaps more faithful to Benjamin's most radical statements on destruction and "the destructive character," consists in preserving both the purity of divine violence and the necessity of its contamination in law. According to Werner Hamacher, the "afformative" of pure divine violence "cannot help becoming what it is not and will always have become what it never was: the atemporal relinquishes itself to the time of positing, of representation, and of duration, exposing 'itself' to the dialectics of imposition and decay" (1994: 129). But the necessity of this "law of bastardization" does not preclude the purity of divine violence and of its destructiveness with regard to law-positing violence. It "cannot help but preserve itself in the diversity of performatives." Nonetheless, Hamacher remains faithful to Benjamin inasmuch as he maintains that no criterion can be found to identify the annihilating force of divine violence as such: the justice of pure divine violence is strictly non-ontological and non-human, it is the pure ex-positing of all forms. In this way, Hamacher conceives of divine violence as "preontological" or "transontological" (or, perhaps, as meontological). (3) The third interpretation consists in thinking the possibility of contamination first, before ontology, and to tarry with the impure and equivocation. Derrida (2002) writes: "The suffering of deconstruction, what makes it suffer and what makes suffer those who suffer from it, is perhaps the absence of rules, of norms, and definitive criteria to distinguish in an unequivocal manner between law and justice. It is therefore a matter of these concepts (normative or not) of norm, of rule or criteria. It is a matter of judging what permits judgment, of what judgment itself authorizes" (231). Deconstruction supposes the heterogeneous co-implication (differential contamination) between law and justice, and the relentless deconstruction of legal violence (power) in the name of unpresentable justice. The question remains to know whether it is possible to construe justice, democracy, or any political experience in an absolute nonrelation to 
It is on the basis of this proto-ontological logic of purity, which undergirds the thought of pure violence uncontaminated by law, that Agamben's reading of Benjamin can translate pure divine violence in the form of an explicit ontology -one that is also indexed on a logic of purity and the refusal of contamination. What Agamben targets is the violence of sovereignty, of any legal system (be it fascist, totalitarian, or democratic) which, through the law of exception that is the privilege of sovereign power, fractures and captures human life and praxis to command and govern it as if from the outside -and to do so with violence (remember Aristotle's definition of violence). Agamben describes this process of heteronomic capture by the "juridico-political machine," the "biopolitical machine" of the West, as well as its potential destitution, in the prophetic last paragraphs of State of Exception:

Politics has suffered a lasting eclipse because it has been contaminated by
law, seeing itself, at best, as constituent power (that is, violence that makes
law), when it is not reduced to merely the power to negotiate with the law.
The only truly political action, however, is that which severs the nexus
between violence and law. And only beginning from the space thus
opened will it be possible to pose the question of a possible use of law
after the deactivation of the device that, in the state of exception, tied it to
life. We will then have before us a "pure" law, in the sense in which Ben-
jamin speaks of a "pure" language and a "pure" violence. To a word that
does not bind, that neither commands nor prohibits anything, but says only
itself, would correspond an action as pure means, which shows only itself,
without any relation to an end. And, between the two, not a lost original
state, but only the use and human praxis that the powers of law and myth
had sought to capture in the state of exception. (2005a: 88, my emphasis)

Everything hinges, then, on the possibility for a pure language or pure violence to say or show itself, as pure means, self-manifestation, without ever being "contaminated" or bastardized by law. As illustrated in this passage, Agamben's reading of Benjamin seems to work from the assumption that nonviolence and pure divine violence chiasmically cross each other in and through the politics of pure means. The goal, then, is to retrieve the possibility of a purely non-instrumental language, a "truly political action," a use (uso), or a life that would be purely external to law, uncontaminated by law -a pure language, action, use, or life in which language, action, use, and life are not means to an end, but pure potentiality, pure potential, pure potenza. ${ }^{12}$

law and power. If that were possible, would this nonrelation be purely external to power and law? Or would it be an internal-externality, the trace of a constitutive impurity and irreducible heterogeneity in the "form" (or "force") of the event to come? This would be Derrida's interpretation of democracy-to-come as impure negotiation between self-presence and otherness that is, self-deconstruction at work: democracy-to-come as "a self-deconstructive force" (2005: 105).

12 Potenza, just like the French puissance, designates a potentiality (dynamis) in relation to actuality (energeia), but preserves a certain connotation of force or might, which is relatively lost in the English "potential" or "potentiality." With that in mind, I sometimes translate it as "potency" -also with an eye towards the sexual connotations of the term (a certain "performance"). I have more to say about these translation issues elsewhere (Mercier, 2018). The 
For all these reasons, the formal logic underlying Agamben's messianic tone requires not only the logic of purity, but also the necessity that said purity remains pure and escapes until the possibility of its contamination by law, justifying narratives, effects of signification, communication, and representation, impure logics of instrumentalization, economies of actualization, and so on. Agamben's intent is "to conceive of being beyond the principle of sovereignty" (1998: 48). He does so through the elaboration of what he calls an "ontology of potentiality" (ontologia della potenza):

\begin{abstract}
Until a new and coherent ontology of potentiality (beyond the steps that have been made in this direction by Spinoza, Schelling, Nietzsche, and Heidegger) has replaced [my emphasis: avrà sostituito] the ontology founded on the primacy of actuality and its relation to potentiality, a political theory freed from the aporias of sovereignty remains unthinkable. (1998: 44)
\end{abstract}

This process of replacement or substitution -the effectuation of which is the central object of the Homo Sacer series, though it was arguably prefigured in many of Agamben's previous works- culminates in The Use of Bodies (2015), wherein Agamben identifies divine violence with the possibility of a "purely destituent potency" (potenza puramente destituente). Based on further readings of Benjamin, Agamben indicates the possibility of purely anarchist politics, of a real state of exception beyond the virtual state of exception instituted by sovereign law and the biopolitical machine. Agamben's ontology of potentiality thus postulates a politics of singularity presenting itself as "form-of-life": "what has been divided from itself and captured in the exception life, anomie, anarchic potential [potenza]- now appears in its free and intact form" (272-3). The form-of-life in question is defined as a life-potential that cannot be separated from its form, human life as pure potential: "a life-human life- in which singular modes, acts, and processes of living are never simply facts but always and above all possibilities of life, always and above all potential" (207).

Agamben associates the destituent potency of divine violence with a potentiality (dynamis) not to pass into the act (energeia), into the work (ergon). The exhibition of this potentiality-not-to -a pure potentiality (potenza) which is quite as much an impotentiality (adynamia, impotenza) - is based on a series of intricate readings of Aristotle, and is certainly one of Agamben's most constant gestures. ${ }^{13}$ And for good reasons: in bypassing the teleo-logic of actuality (energeia), pure potenza as impotenza maintains an ontological space of inoperativeness without ergon, in which the means-ends structure is essentially deactivated. Pure potentiality could thus instantiate an intensive politics of pure means and the type of destituent politics which Agamben associates with true anarchism -as immediate manifestation of human life and praxis beyond law. However, Agamben's efforts to isolate a pure potentiality-not-to (pass into the act) do not go without many difficulties. One difficulty, which Agamben describes in the first

question of "performativity" in relation to violence, power, and resistance is also central in my PhD dissertation, and in Mercier (2016).

${ }^{13}$ In addition to the Homo Sacer series, see Agamben, 1999 and 2019. Elsewhere, I analyzed in detail Derrida's deconstruction of the dynamis-energeia structure, notably through notions such as the force of the event, puissance, and the potence of the im-possible (Mercier, 2018). 
volume of Homo Sacer, in the context of a critical reading of Antonio Negri, is that the potentiality-not-to can also become an attribute of sovereign power, which can always appropriate said "impotentiality": sovereign power can always not pass into the act, while sovereignly maintaining its power as pure potentia. This is why Agamben is suspicious -I believe rightly so- of Negri's ontological conception of purely constituent power as pure potentia without actualization, without potestas or constituted power. With that in mind, Agamben's goal is thus to conceive of a pure potenza or impotenza that could in no way characterize power as constituent power (or potentia) -that is, a purely destituent potency, a potentiality-not-to that would not exhaust itself in the passage into actuality, and which he calls inoperativeness or désoeuvrement:

The only coherent way to understand inoperativeness is to think of it as a mode of generic existence of potentiality [potenza] that is not exhausted (like individual action or collective action understood as the sum of individual actions) in a transitus de potentia ad actum. (1998: 62, translation modified)

With that being said, it is worth noting that, even though this pure potentiality (as impotentiality) is thought of as non-power, it is also conceived of by Agamben as a capacity: it supposes "to be capable [potere] not of possibility and potentiality [potenza] but of an impossibility and impotentiality [impotenza]" (1999: 202). Impotentiality can and should be appropriated in the form of a poter-non, a being-able-notto. ${ }^{14}$ In one of Agamben's readings of Heidegger, impotentiality espouses a certain onto-logic of the proper, even though it is a matter of being properly improper: "If what human beings must appropriate here is not a hidden thing but the very fact of hiddenness, Dasein's very impropriety and facticity, then 'to appropriate it' can only be to be properly improper, to abandon oneself to the inappropriable" (1999: 202). Agamben's thinking of impotentiality and inoperativeness thus designates humankind's capacity to own its own impotentiality, defined as appropriation of its own improperness. ${ }^{15}$ This is important because, just like the logic of purity, the logic of property remains necessary so that the potentiality-not-to of purely destituent potency

\footnotetext{
${ }^{14}$ See Agamben (2019). On different premises than mine, David Johnson (2007) convincingly argued that Agamben's pure potentiality cannot not resemble the sovereign power against which it is posited-especially when it comes to the appropriation of presence in the form of messianic time.

${ }^{15}$ This is a crucial difference between Agamben's thinking of impotentiality (indexed on the anthropo-onto-logic of the pure and the proper) and Derrida's thinking of (non-negative) impossibility, which is irreducible to ontological (im)potentiality and cannot be "appropriated" in any conceivable way. According to Agamben, Derrida's deconstruction of presence and ontology can only result in paralysis, powerlessness and blocked messianism: "Deconstruction is a thwarted [bloccato] messianism, a suspension of the messianic" (2005b: 103). By contrast, Agamben offers a messianic dynamology. But what is the messianic if it doesn't address itself to the other's impossible, inappropriable event? Probably just a reproduction of the Western metaphysical figure of messianism, inasmuch as it has always been predicated on the teleologic of dynamis-energeia and the juridical-political machine it undergirds. On these themes, see Johnson (2007) and Mercier (2018).
} 
remains critically distinct from sovereign or constituent power, in potentiality and in act. Even as impotential, it must preserve a certain critical power. And this critical power lies in the possibility that purely destituent potency, as pure manifestation, pure means, is and remains structurally emancipated from the teleology of dynamis-energeia, from the means-ends structure, and from the juridical order:

Benjamin here has in mind a "pure means," namely, a means that appears as such, only insofar as it emancipates itself from every relation to an end. Violence as pure means is never a means with regard to an end: it is attested only as exposition and destitution of the relationship between violence and juridical order, between means and end. (Agamben, 2015: 269)

Pure violence and pure means must be attested. In the same manner that pure language (the language of nomination) designates "the only language that does not mean anything but simply speaks" (1999: 54), that is, language's manifestation as pure potential without communication and without signification, pure destituent violence can be attested as such only if it is and remains purely destituent-only if it does not result in any law or ergon of any sort, only if it refers only to its own inoperativeness: it must be and remain purely self-referential. ${ }^{16}$ Agamben's reading of divine violence as purely destituent potency thus sidesteps the equivocations and difficulties of Benjamin's text with respect to divine violence, starting with its uninterpretability. In Agamben's description, inoperativeness and destitution must be attested and identifiable as such, as pure means, as the very force or intensity of their potent inoperativeness. They must be and remain pure. If not, they would lose their potency as pure violence, and the whole architecture of Agamben's politics of pure means would become impure, "contaminated by law." Since what is at stake here is nothing less than the destitution of the whole Western theoretical-political machine, of all juridical violence and the biopolitical logic of sovereignty, there is of course a lot to consider.

If we admit-concesso non dato- that (1) pure destituent potency, potentiality-notto, can be conceived and identified as such, in all purity, as potentiality that would be and remain pure in and through the passage of potentiality into the act or ergon; and (2) (more problematically even) that it can be stabilized into an ontology that remains unsubordinated to the act and to the whole dynamis-energeia teleology, emancipated from the autotelic structure of the ergon that is being destituted or deposed in the inoperativeness ${ }^{17}$-one massive problem still remains: purely destituent potential is not nothing. It has ontological potency. It is not nothing, and it does something, even though what it does cannot be understood as act or ergon. Even though

16 "In [Benjamin's] essay on language, pure language is that which is not an instrument for the purpose of communication, but communicates itself immediately, that is, a pure and simple communicability; likewise, pure violence is that which does not stand in a relation of means toward an end, but holds itself in relation to its own mediality. And just as pure language is not another language, just as it does not have a place other than that of the natural communicative languages, but reveals itself in these by exposing them as such, so pure violence is attested to only as the exposure and deposition of the relation between violence and law" (Agamben, 2005a: 62).

17 ....another way of saying that, as long as désoeuvrement is conceived as inoperativeness of an ergon, it must probably be thought, at the very least, as a sort of parergon-or hors-d'oeuvre. 
inoperativeness is defined by the absence of work, of ergon, as soon as it does not do nothing, as soon as it does something, as soon as it has effects, it must leave traces. Unless, of course, one considers inoperativeness as absolute ex-position without traces and without remainder, as the meontological excavation of being itself -but this is certainly not Agamben's interpretation of divine violence. ${ }^{18}$ As soon as pure destituent potency leaves traces, these can be interpreted: they are left to the other's interpretation. Self-referentiality derives into hetero-referentiality. Pure manifestation into re-presentation. Pure intensity becomes text. The erection of (im)potency falls, like a case. Impotenza can be read as potenza, and vice versa. Certainly, traces are not reducible to "acts," "erga," even less "laws"; but they can always be interpreted in this direction. They are open to interpretations, and can always be deciphered, studied, evaluated, examined, justified, mythicized, mythologized, and so on. Traces are not signs, but they can always become signs, symptoms, clues, indications, pieces of evidence in a logic of testimony. They can make the case. They may always be interpreted as ends or as means through the mekhane of a machination. This may always happen, quasi-automatically, as if by magic. If the pure violence of destitution can be interpreted through what it does, through the traces it leaves, it may always become impure, "contaminated" by the teleology of myth and law: pure means can be reinscribed within the means-ends structure through effects of signification, representation, referentiality; and pure (im)potentiality can be interpreted as act, as work, reappropriated within an economy of exchange, of law, a certain market. Traces can always be put to work. And one must think the possibility of this derivation and contamination before pure destitution and manifestation.

This possibility exists as soon as the pure must be inscribed. It already happens in Agamben's text, as soon as Agamben must inscribe pure violence within a classification -as soon, for example, as he must define pure potentiality in opposition to sovereignty, as soon as he describes impotentiality as the human proper, as soon as he inscribes his work within the Western canon, and as soon as he must take examples of inoperativeness, examples which can always be reinterpreted as works: the poem, festivities, the pure potency of thought, Plato's Nocturnal Council, pure language, and so on and so forth. Above all, this possibility exists as soon as Agamben presents inoperativeness and pure violence as a critical device, as the very foundation of "every properly critical instance" (2019), one that allows to distinguish between violences, to draw lines between good or bad violences, between self-referentiality and heteronomy, between anarchy and power, between pure and impure anarchies, between the

\footnotetext{
${ }^{18}$ I cannot do justice here to Hamacher's stunning reading of Benjamin, but let's note that it precisely goes against any attempt to retrieve pure divine violence through a humanist politics or ontology (such as Agamben's). In protecting the purity of the ex-positing violence of the afformative against any positive content whatsoever, Hamacher refutes in advance all translation of destituting violence into an anarchist (humanist or ontological) political program of any sort: "If the order of the 'moral world' is imagined as an order of acts and methodical operations, then historical time, as Benjamin represents it [...] [is] the 'nothing' of nonoperationality. It is the omission and the epoché within every execution, and only thus does it interrupt the guilt economy without continuing it" (2002: 105). I hope to discuss Hamacher's interpretation of Benjamin and compare it with Derrida's in future works.
} 
"truly political" and the "juridical-political," between proper improperness and improper properness, etc. By distributing between purity and impurity, between justice and law, between destituent and constituent potencies, between the proper and the improper, Agamben's ontology participates in the economy of violence and justification. It starts to resemble the legal-political machine against which it was built. It repeats, otherwise, the philosophical scene of violence-one which strives to instantiate, always differently, its own ethical-political sovereignty as critical instance and power of decision and interpretation, thus re-producing "the ethical instance of violence."

\section{TREMBLING: Of DECONSTRUCTION'S RESPONSIBILITIES ("IL FAUT...")}

By way of conclusion, I would like to reflect on the implications of Derrida's thinking of violence, contamination, and impurity in relation to responsibility. In several works, Martin Hägglund attempted to approach deconstruction as a purely analytical endeavor without any prescriptive claim:

Whether a given struggle should be supported or resisted is a different question, which cannot be answered through deconstructive analysis and requires concrete political engagement. It is precisely by not providing an ethical or political principle of any kind that deconstruction politicizes our actions and insists on a responsibility from which one cannot be absolved. (2011: 149-50)

Here, as always, Hägglund proceeds to disjoin "the ethical" from "the descriptive," and puts all the weight of deconstruction ("deconstructive analysis") on descriptivity. "Deconstructive analysis" does not prescribe anything; it doesn't provide any principle for "concrete political engagement," and this is why, according to Hägglund, it allows for maximum responsibility (which Hägglund calls "hyperpolitical"). Hyperpolitical responsibility supposes the purification of responsibility, decision, and political engagement from any ethico-political rules, principles, or programs. ${ }^{19}$ Hägglund exposes

${ }^{19}$ But, precisely, the trace-structure commands that such purification can never take place. In Radical Atheism, Hägglund (2008) attempted to define responsibility in relation to violence. Characteristically, he describes aporetic conditions of possibility as conditions of negative impossibility, and emphasizes the necessity of violent discrimination: "What makes it possible to be responsible is thus at the same time what makes it impossible for any responsibility to be fully responsible. Responsibility, then, is always more or less discriminating, and infinite responsibility is but another name for the necessity of discrimination" (94-95). As often in Hägglund's book, this responsibility (possible as impossible) is assigned to a phantasmatic "I" -an "I" that must make difficult choices, negotiate between such or such violence: "If I did not discriminate between what I welcome and do not welcome, what I find acceptable and unacceptable, it would mean that I had renounced all claims to be responsible, make judgments, or pursue any critical reflections at all" (103). One can see here the "philosophical scene" I was describing in my introduction: it involves the krinein of a critical subject, sometimes a "deconstructive thinker," faced with impossible decisions "in a given situation" (106). But who is that subject? And is such a "situation" ever "given"? Does it ever present itself as such? While he tries to account for Derrida's aporias of decision and responsibility, Hägglund still reproduces the "ethical instance of violence," though he re-marks it with negative impossibility. But, as Derrida explains in Aporias, "the aporia can never simply be endured as such. The ultimate aporia is the impossibility of the aporia as such" (1993: 78). Deconstruction does not signify 
this problem through a critique of John Caputo's "misreading of Derrida" (136); Hägglund argues that deconstruction does not prescribe that "we" open ourselves to the other, rather than protecting ourselves against it:

Contrary to what Caputo proposes, deconstruction does not hold that we should seek to expose ourselves rather than to be safe, to take risks rather than seek protection. To posit such a principle is to deny the autoimmunity of exposure and protection, safety and risk, which entails that the advantage of one over the other cannot be given in advance. (2011: 150)

From a certain perspective, Hägglund's argument on the non-prescriptivity of deconstruction might well be "right" -but his argument remains problematic and onesided (Naas, 2009: 49). It is so because it presupposes the philosophical-critical scene and the ethical instance of violence: Hägglund works within the assumption of the present time of krisis, one over which the ipseity of a subject does not have full mastery, one in which "I" (or "we") cannot know "in advance" the benefits of my actions. On this presentational "scene," the critical subject must strategically negotiate within a certain economy of violence, cannot calculate "in advance" "risks" and "advantages," and cannot decide what the most ethical, the least violent decision might be in a given situation according to pre-established principles, rules, or programs. From the perspective of this "scene," one might say that, perhaps, Derrida does not prescribe any "principle" as to the attitude one might choose in any given situation. There is no pre-programmed strategy. Maybe... But the point of deconstruction is precisely to deconstruct this "scene," to think what makes it possible and impossible as such, to expose it and show that it never presents itself as such, that it cannot be posited as such. The "scene" Hägglund describes is a philosophical abstraction, a phantasm predicated on the logic of ipseity. "Decision" is not a matter of "choosing" between "exposure" and "protection." What Hägglund calls "protection" has alwaysalready been pre-exposed: "What happens is always some contamination" -"and impurity here is chance." The impure is our "milieu," so to speak, our "ecosystem" or our "economy" -it is probably not even "ours." This is why, although deconstruction strives to "suspend" "the ethical instance of violence" (all critical principles, rules, programs which teleguide our sense of violence), it also affirms that this suspension can never be pure, that the "scene" of suspension can never present itself, as such, in the presence of the present. Responsibility is never pure, not because it must always "discriminate," and do so violently, but mainly because responsibility is always preinterrupted by "the pre-originary intervention of the other" -a self-interruption, a différance which makes responsibility an originary response, an arche-originary gage (Derrida, 2005: 244): the opening of responsibility is heteronomic, impure, without

the necessity for an "I" to critically discriminate between others "in a given situation." On the contrary, deconstruction targets the scene of the critical instance "itself," and its discriminating power. It suggests that one is always-already robbed of this "situation," of this "scene." It recalls the necessity ("il faut...") of trembling and deconstruction before "discrimination"; of impure contamination between self and other before the position of an "I," one who could say "l," as in: "I am ir/responsible," "I discriminate," "I am violent/nonviolent," "just/unjust," and so on. Here again, Hägglund ignores the contaminating effects of text, of traces (which are not simply "of" time) -the traces of a text that deconstructs itself, and of which we are the effects. 
origin. This opening -which is the motif of deconstruction- never presents itself as such, but it pre-robs subjective ipseity from any claim to pure decision or responsibility. It remains, by the same token, the condition for the relation to the other: it opens to both violence and nonviolence. It signifies a "strange violence" at the origin of any responsibility, sociality, or "concrete political engagement." Therefore, it places responsibility under the law of an irreducible heterology. It is on the backdrop of this heterological responsibility that juridical responsibilities can be assigned, and that specific strategies may be negotiated -in impurity. This, of course, is nothing short of scandalous from the perspective of traditional ethical or empirical discourses on violence. It is terrifying. It supposes a trembling -not only the trembling between violences, "mine" or the other's, or the other's others, but the violence of trembling "as such," when there is no "as such":

The trembling worthy of the name makes an "I" tremble to the point that this "I" can no longer posit itself as the subject (active or passive) of a violent trembling which happens to it [qui lui arrive], of an event which deprives it of its mastery, of its will, of its freedom, therefore of its right to ipseity, that is, to the power to think or to say to itself, auto-affectively, "I" and, as any ipseity signifies, to the power tout court, the "I can" tout court, or the "I can know," "I can decide," "I can assume a responsibility that is mine only, and not an other's." Trembling makes the "I"'s autonomy tremble, it places it under the other's law -heterologically. (Derrida, 2006: 94, my translation $)^{20}$

One trembles -violently- because there is text. Because when it comes to interpret, describe, denounce, justify, or critique violence -that is, a virtually unlimited field of

\footnotetext{
${ }^{20}$ In Scatter 1, Geoffrey Bennington (2016) also associates trembling with impurity, and recalls that Derrida said that "the trembling worthy of the name does not exist" (268). In The Gift of Death, Derrida articulated trembling to the experience of a certain violence that remains, and remains to come: "trembling, at least as a signal or symptom, is something that has already taken place, as in the case of an earthquake [tremblement de terre] or when one trembles all over. It is no longer preliminary even if, unsettling everything so as to imprint upon the body an irrepressible shaking, the event that makes one tremble portends and threatens still. It suggests that violence is going to break out again, that some traumatism will insist on being repeated. As different as dread, fear, anxiety, terror, panic, or anguish remain from one another, they have already begun in the trembling, and what has provoked them continues, or threatens to continue, to make us tremble. Most often we neither know what is coming upon us nor see its origin; it therefore remains a secret. We are afraid of the fear, we anguish over the anguish, and we tremble. We tremble in that strange repetition that ties an irrefutable past (a shock has been felt, a traumatism has already affected us) to a future that cannot be anticipated; anticipated but unpredictable; apprehended, but, and this is why there is a future, apprehended precisely as unforeseeable, unpredictable; approached as unapproachable. Even if one thinks one knows what is going to happen, the new instant of that happening remains untouched, still unaccessible, in fact unlivable. In the repetition of what still remains unpredictable, we tremble first of all because we don't know from which direction the shock came, whence it was given (whether a good surprise or a bad shock, sometimes a surprise received as a shock); and we tremble from not knowing, in the form of a double secret, whether it is going to continue, start again, insist, be repeated: whether it will, how it will, where, when; and why this shock" (1995: 53-54).
} 
discourse or practice, before even the delimitation of experience between discourse and practice, between "description" and "prescription," between "constative" and "performative," and perhaps even before what we call "experience": before and beyond experience as such -one must depart from text/s. Il faut, one must "start" with reference, hetero-referentiality and différance. This is why "violence" is never pure, or can always be made impure: one must refer to make sense of violence. One must refer tout court, where and when there is no pure. The chance of trembling, of the impure, is that it can always shake things up and modify the terrain. Derrida's il faut "one must") points to the irreducible fallibility of a "fault trace" or a "fault line" (ligne de faille), one which can always become a resource for transforming the rules. ${ }^{21}$ But this

${ }^{21}$ I believe this is consistent with two of Rodolphe Gasché's conclusions at the end of his remarkable reflection on deconstruction, force, and violence (2016: 87): 1) "The determinations of deconstruction remain bound essentially to context"; and 2) "deconstruction cannot be determined as a force or as a violent intervention without an irreducible remainder." Yes. I am perhaps less confident about two other conclusions of Gasché's: First, I am not so sure that "the possibility of deconstruction" presupposes and preserves the difference between the "force" and the "violence" of deconstruction -here again I would be tempted to privilege a certain contamination of the impure. But, above all, I am unsure, perhaps a little nervous, about the following idea, according to which contexts can be exhausted -especially when it comes to reading "force" or "violence": "The determinations of deconstruction remain bound essentially to context [that, I think I agree with]. They can be abandoned and replaced by new ones after exhausting the context within which and the subject matter with respect to which these determinations arose." But can a "context" ever be fully exhausted? And who "can" decide on this? I wonder if the law of deconstruction's "irreducible remainder" described by Gasché does not imply, on the contrary, a certain inexhaustibility of contexts, the ever-existing possibility of their return or revenance: the irreducible possibility of a haunting through which what we call "force" or "violence" can always return, as impure as text, in and through the insistence of self-deconstruction -thus prohibiting the a priori exclusion of the iterability of any context whatsoever. And since context matters, here and anywhere, I want to mark the context in which the present article was written -a context which has produced new scenes of violence, reproduced old ones, and perhaps transformed the "question" of what we call "violence" in ways which remain to be analyzed. This "context," heterogeneous and differentially entangled, involves at least a double fault line, a shared trembling in différance and division: 1) first, the COVID-19 pandemic and the series of bio-political-juridical policies which have been implemented in response, for better or worse, with massive differences on national and international levels, and with effects that remain very difficult to calculate. Notoriously, Agamben vehemently denounced these measures of exception, likening them to totalitarian and fascist policies. In addition, the pandemic has brought to light a multitude of inequalities and intersectional violences on the global and local scales, and has become the subject of innumerable ideological, economic, ecological, technoscientific, and sociopolitical debates. 2) Antiracist protests in the US and across the world following the murder of George Floyd, denouncing police violence and the sedimented effects of systemic racism, white supremacy, and colonialism. This double "context," this differential trembling has already modified the coordinates of the discourse on violence, including its articulation to questions of legitimacy and power. Even though the extent and implications of current events are very difficult to evaluate, and without having too many illusions about the transformative capacities of theoretical analytics, I hope that the type of deconstructive formalization of violence laid out in the present essay can help to approach this non-closed, highly instable context of which we are also the effects, to interpret and accompany the ways in which the very meaning of violence finds itself 
trembling transformation tarries with contamination. Hence the impossibility to escape once and for all the economy of violence and justification from an empirical or theoretical standpoint. Absolute certainty about the pure essence of pure violence would amount to absolute certainty about the justness of my reading of it: it would be the ground for divine justice. What we have, however, is different. This law of differantial contamination is the law of text:

This is one of the reasons we always set out from texts for the elaboration of this problematic, texts in the ordinary and traditional sense of written letters, or even of literature, or texts in the sense of differantial traces according to the concept we have elaborated elsewhere. And we are unable to do otherwise than take our departure in texts insofar as they depart (they separate from themselves and their origin, from us) at the departure [dès le départ]. We could not do otherwise even if we wished to do so or thought to do so. We are no longer credulous enough to believe that we are setting out from things themselves by avoiding "texts" simply by avoiding quotation or the appearance of "commentary." (Derrida, 1992b: 100)

\section{BIBLIOGRAPHY}

AGAMBEN, Giorgio. (1998). Homo Sacer. Sovereign Power and Bare Life. Stanford: Stanford University Press.

— (1999). Potentialities: Collected Essays in Philosophy. Stanford: Stanford University Press.

— (2005a). State of Exception. Chicago: The University of Chicago Press.

- (2005b). The Time That Remains: A Commentary on the Letter to the Romans. Stanford: Stanford University Press.

— (2015). The Use of Bodies. Stanford: Stanford University Press.

- (2019). Creation and Anarchy: The Work of Art and the Religion of Capitalism. Stanford: Stanford University Press.

ARISTOTLE. (2011). Nicomachean Ethics. Chicago: The University of Chicago Press.

BENJAMIN, Walter. (1996). Selected Writings. Volume 1. Cambridge: Harvard University Press.

BENNINGTON, Geoffrey. (2016). Scatter 1: The Politics of Politics in Foucault, Heidegger, and Derrida. New York: Fordham University Press.

BERNSTEIN, Richard. (2013). Violence: Thinking Without Bannisters. Cambridge: Polity Press.

deconstructed and in which the limits between violence and nonviolence, acceptable and inacceptable violences, legitimacy and illegitimacy tremble and are displaced -while preserving, as much as possible, the irreducible singularity of events that remain at bottom inappropriable and inexhaustible. 
BOSTEELS, Bruno. (2017). "Critique of Originary Violence: Freud, Heidegger, Derrida." The Undecidable Unconscious, 4, 27-66.

BUTLER, Judith. (2020). The Force of Nonviolence: An Ethico-Political Bind. London and New York: Verso.

CAMPOS-SALVATERRA, Valeria. (2019). "The Original Polemos: Phenomenology and Violence in Jacques Derrida." In G. Rae and E. Ingala (eds). The Meanings of Violence: From Critical Theory to Biopolitics. New York: Routledge.

DERRIDA, Jacques. (1978). Writing and Difference. London and New York: Routledge.

— (1981). Dissemination. London: The Athlone Press.

— (1988). Limited Inc. Evanston: Northwestern University Press.

— (1992a). Acts of Literature. New York and London: Routledge.

- (1992b). Given Time: I. Counterfeit Money. Chicago: The University of Chicago Press.

— (1993). Aporias. Stanford: Stanford University Press.

— (1995). The Gift of Death. Chicago: The University of Chicago Press.

— (1996). "Remarks on Deconstruction and Pragmatism." In C. Mouffe (ed). Deconstruction and Pragmatism. London and New York: Routledge.

— (1997). Of Grammatology. Corrected Edition. Baltimore: The Johns Hopkins University Press.

— (2001). A Taste for the Secret. Cambridge: Polity Press.

— (2002). Acts of Religion. New York and London: Routledge.

— (2005). The Politics of Friendship. London and New York: Verso.

— (2006). "Comment ne pas trembler?" Annali: Fondazione europea del disegno (Fondation Adami), 2, 91-104.

GASCHÉ, Rodolphe. (2016). Deconstruction, Its Force, Its Violence. Albany: SUNY Press.

HÄGGLUND, Martin. (2008). Radical Atheism: Derrida and the Time of Life. Stanford: Stanford University Press.

HÄGGLUND, Martin. (2011). "The Radical Evil of Deconstruction: A Reply to John Caputo." Journal for Cultural and Religious Theory, 11 (2), 126-150.

HAMACHER, Werner. (1994). "Afformative, Strike: Benjamin's 'Critique of Violence.'" In A. Benjamin and P. Osborne (eds). Walter Benjamin's Philosophy: Destruction and Experience. London and New York: Routledge.

- (2002). "Guilt History: Benjamin's Sketch 'Capitalism as Religion." Diacritics, 32 (3-4), 81-106. 
HANSSEN, Beatrice. (2000). Critique of Violence. Between Poststructuralism and Critical Theory. London and New York: Routledge.

JOHNSON, David. (2007). "As If the Time Were Now: Deconstructing Agamben." The South Atlantic Quaterly, 106 (2), 265-290.

MARTEL, James. (2015). "The Anarchist Life we are Already Living: Benjamin and Agamben on Bare Life and the Resistance to Sovereignty." In B. Moran and C. Salzani (eds). Towards the Critique of Violence: Walter Benjamin and Giorgio Agamben. London and New York: Bloomsbury Academic.

MORAN, Brendan and SALZANI, Carlo. (2015). "Introduction: On the Actuality of 'Critique of Violence.'" In B. Moran and C. Salzani (eds). Towards the Critique of Violence: Walter Benjamin and Giorgio Agamben. London and New York: Bloomsbury Academic.

MERCIER, Thomas Clément. (2016). "Resisting Legitimacy: Weber, Derrida, and the Fallibility of Sovereign Power." Global Discourse, 6 (3), 374-391.

- (2018). "We Have Tasted the Powers of the Age to Come: Thinking the Force of the Event -from Dynamis to Puissance." Oxford Literary Review, 40 (1), 76-94.

NAAS, Michael. (2009). "An Atheism that (Dieu merci!) Still Leaves Something to be Desired." CR: The New Centennial Review, 9 (1), 45-68.

SCHEURMANN, Ingrid and Konrad (eds). (1992). Für Walter Benjamin. Dokumente, Essays und ein Entwurf. Frankfurt am Main: Suhrkamp.

VITALE, Francesco. (2018). Biodeconstruction: Jacques Derrida and the Life Sciences. New York: SUNY Press.

ŽlŽEK, Slavoj. (2016). Against the Double Blackmail: Refugees, Terror and Other Troubles with the Neighbours. London: Allen Lane. 